\title{
ATRIBUT DESTINASI PARIWISATA DAN KUALITAS PELAYANAN MEMPENGARUHI NIAT WISATAWAN BERKUNJUNG KEMBALI DI PANTAI MELASTI, DESA UNGASAN, KABUPATEN BADUNG
}

\author{
Made Riki Ponga Kusyanda \\ Prodi Magister Pariwisata Universitas Udayana \\ E-mail: riki.ponga@gmail.com \\ Made Antara \\ Universitas Udayana \\ E-mail: antara_unud@yahoo.com \\ I Gusti Ayu Oka Suryawardani \\ Universitas Udayana \\ E-mail: gungdani@gmail.com
}

\begin{abstract}
The urgency of this research was the utilization of Melasti Beach's trough a professional management operational, it can provide economic benefits for Ungasan Village, one of the point is creating guest satisfaction and re-visit intention continuesly. The goals of these study was (1) Analyze the effect of tourism destination attributes toward guest re-visit intention of tourists on Melasti Beach trough the guest satisfaction as the intervening , (2) to analyze the effect of service quality toward re-visit intention into Melasti Beach trough the guest satisfaction as the intervening (3) to anlyze the effect of guest satisfaction toward revisit intention . The sample of this study was 100 tourists consisting for domestic and foreign tourist. Using incidental sampling method to reach the respondent. Primary data is obtained through questionnaires. The data analysis method used is a quantitative approach and using structural equation models- partial least square or Smartpls version 3.0 and also described by descriptively to conduct the research. The finding of thes study is almost all of the hypothesis is accepted, except hypothesis no. 4 were rejected due to there were no significant relation between service quality toward tourist re-visit intention, and hypothesis no. 6 were there was no significant influence on tourism destination attribute toward tourist intention re-visit intention through tourist satisfaction. The advice of these research generally advice to keep the tourism destination attribute as the determinant factor, in how to effect the revisit intention by the guest in the near future.
\end{abstract}

Keywords: Tourism destination attributes, service quality, tourist satisfaction, tourist revisit intention. 


\section{Pendahuluan}

Desa Ungasan sebagai salah satu Desa yang terletak tepat dikaki paling selatan Pulau Bali. Dianugerahi bentangan alam yang indah, sehingga memiliki tempat yang dapat dimakasimalkan untuk kunjungan wisatawan, khusunya wisata bahari. Satu dari sekian tempat tersebut adalah Pantai Melasti. Sejak ditetapkan sebagai daya tarik wisata melalui PERBUB Badung No. 4 Tahun 2018 pengembangan daya tarik wisata Pantai Melasti semakin gencar dilakukan. Sebelumnya, sudah terdapat kajian mengenai usulan Pantai Measti sebagai daya tarik wisata. Kajian tersebut dijelaskan secara eksplisit ingin menjadikan Pantai Melasti sebagai Daya Tarik Wisata yang professional dalam hal manajemen dan pengelolaan operasional dilapangan. Salah satu poin pada kajian akademik yang dilakukan oleh Diarta, (2018), yaitu menciptakan kepuasan wisatawan dan loyalitas atau kunjungan kembali wisatawan di Pantai Melasti. Secara jelas disebutkan tujuan pengemabngan melalui pemanfaatan potensi yang dimiliki Pantai Melasti diarahkaan kepada pengelolaan yang professional untuk mendapatkan manfaat ekonomi itu sendiri. Pelayanan yang professional dalam upaya meningkatkan kepuasan wisatawan merupakan salah satu komponen penting (Kozak dan Rimington, 1999). Selain itu menurut Lee (2011), menetukan atribut destinasi pariwisata merupakan salah satu komponen penting dalam menimbukan niat untuk berkunjung kembali wisatawan ke suatu destinasi pariwisata.

Selain itu urgensi dari penelitian ini adalah pemanfaatan potensi Pantai Melasti berupa atribut destinasi pariwisata dan kualitas pelayanan untuk menciptakan kepuasan dan niat kunjungan kembali wisatawan yang dapat memberikan manfaat ekonomi bagi Desa Adat Ungasan untuk membiayai kegiatan Tri Hita Karana setiap tahunnya yang menjadi beban besar bagi Desa Adat dan memberikan kesejahteraan, baik bagi masyarakat yang terlibat langsung dalam aktifitas kepariwisataan maupun yang tidak terlibat secara langsung. 
Bertitik tolak pada kajian akademis terdahulu dan urgensi yang dihadapi Desa Adat Ungasan maka rumusan masalah penelitian ini yang menjadi pertanyaan yang harus terjawab pada studi ini yaitu, (1) Bagaiamana pengaruh atribut destinasi pariwisata terhadap kepuasan wisatawan melalui kepuasan wisatawan di Pantai Melasti, (2) Bagaimana kualitas pelayanan mempengaruhi kepuasan wisatawan melalui kepuasan wisatawan di Pantai Melasti, (3) Bagaimana kepuasan wisatawan mempengaruhi keinginan wisatawan berkunjung kembali di Pantai Melasti Ungasan.

\section{Teori dan konsep yang mendukung penelitian}

\section{Perilaku Wisatawan}

Menurut Solomon, 1996 (dalam Cohen, et al , 2014), konsep perilaku konsumen melibatkan keputusan, kegiatan, ide atau pengalaman tertentu yang memuasakan suatu kebutuhan dan keinginan konsumen. Menurut Cohen, et al , (2014), adapun konsep dari perilaku wisatawan yaitu: pengambilan keputusan, nilai, motivasi, konsep pribadi dan kepribadian, ekspektasi, sikap, persepsi,kepuasan, kepercayaan dan loyalitas.

\section{Atribut Destinasi Pariwisata}

Menurut Cooper et al, 1993 (dalam Diarta,2018) dalam pengembangan suatu destinasi pariwisata haruslah memenuhi unsur 4A yaitu, attraction, accessibility, amenities, ancillary service). Menurut Jani et al, (2009) destinasi pariwisata terdiri dari atribut yang multi dimensi dari suatu perjalanan dimana di dalamnya termasuk atmospir, lingkungan dan pelayanan yang membuat wisatawan untuk datang dan tinggal lebih lama pada suatu destinasi

3. Kualitas Pelayanan

Kualitas pelayanan menurut Parasuraman, dkk (1985), bagaimana antara ekspetasi penikmat layanan dan persepsi dibandingkan dengan pengalaman berupa 
layanan yang diterima. Definisi kualitas termasuk: memuaskan pelanggan atau melampaui ekspektasi, layanan yang memenuhi kebutuhan wisatawan baik yang dinyatakan atau tersirat, kesesuaian yang jelas dengan spesifikasi persyaratan yang ditawarkan, kesesuaian ungtuk digunakan dimana produk memenuhi kebutuhan wisatawan dan tidak kurang.

\section{Kepuasan Wisatawan}

Solomon (1992), mendefinisikan bahwa kepuasan wisatawan merupakan keseluruhan rasa atau attitude dari seseorang pada suatu produk setelah membelinya. Kepuasan wisatawan seringkali disebut sebagai jantungnya aktivitas pemasaran (Macheleit \& Mantel, 2001). Hal ini dikarenakan dapat membantu untuk mencapai strategi dan target dalam dunia pemasaran. Penting untuk digarisbawahi bahwa kepuasan pelanggan adalah evaluasi pasca konsumsi baik tidak puas, memenuhi harapan atau melibihi harapan dan didasarkan pada pengalaman keseluruhan (Wang \& Yang, 2004).

\section{Niat Wisatawan Berkunjung Kembali}

Konsep kunjungan kembali wisatawan dapat diartikan keinginan untuk merekomendasikan destinasi pariwisata, dalam hal ini wisatwan mempunyai niatan untuk berkunjung kembali dan merekomendasikan destinasi tersebut ke teman dekat, keluarga dan sekitar karena telah dan sudah melakukan perjalanan wisata dengan puas dan kepuasan ini yang akan diceritakan kepada teman dan sekitarnya sebagai pemasaran dari mulut ke mulut dan wisatawan yang loyal terhadap destinasi wisata (Robertson \& Regula, 1994). Menurut Zeithaml, dkk (2009), niat perilaku masa depan didefinisikan sebagai kesediaan untuk memberikan informasi posiif berdasarkan pengalaman yang dirasakan untuk diceritakan kepada orang lain dan niat untuk melakukan pembelian kembali dimasa mendatang. 
Atribut Destinasi Pariwisata dan Kualitas Pelayanan Mempengaruhi Niat Wisatawan...

\section{Metodologi dan Teknik Analisis Data}

Dasar pengajuan hipotesis berdasarkan atas studi yang pernah dipublikasikan terdahulu dengan detail sebagai berikut: H1: atribut destinasi pariwisata mempengaruhi kepuasan wisatawan (Sharivar,2012; Corte,2015; Gnanapala,2015); H2: kualitas pelayanan mempengaruhi kepuasan wisatawan (Tuan,2012; Al-Ababneh,2013; Ekinci,dkk,2008; Hayati dan Desi,2017; Purnami dan Suryawardani, 2018); H3: atribut destinasi pariwisata memberikan pengaruh terhadap niat wisatawan untuk berkunjung kembali (Nusantini, 2016); H4: kualitas pelayanan memiliki pengaruh pada niat wisatawan untuk berkunjung kembali (Wong\& Erick,2018); H5: kepuasan wisatawan mempengaruhi niat wisatawan berkunjung kembali. (Bintarti \& Kurniawan,2017; Al \& Mohammad,2014; Purnami dan Suryawardani,2018); H6: atribut destinasi pariwisata berpengaruh terhadap niat wisatawan berkunjung kembali dengan kepuasan wisatawan sebagai variable moderasi. (Chan,2018; Nusantini, 2016); H7: kualitas pelayanan mempengaruhi niat wisatawan berkunjung kembali dengan kepuasan wisatawan sebagai variabel moderasi . (Priyanto et, al,2018; Nunkoo,2018; Purnami dan Suryawardani, 2018)

Teknik populasi dan sampel penelitian ini menggunakan 100 responden. Alasannya adalah pertama jumlah kunjungan dipantai Melasti Ungasan tidak dapat di justifikasi sebagai dsasar acuan mengajukan sampel, dikarenakan tiket yang terdistribusi juga dibeli oleh masyarakat lokal desa sehingga tidak memiliki keterwakilan sebagai wisatawan, kedua adalah tiket yang dijual masih memiliki nilai jual yang sama anatra wisatawan mancanegara dengan wisatawan nusantara, sehingga kerangka sampel untuk wisatawan mancanegara atau wisatawan nusantara sejatiya belum ada. Sehingga alternative lain yang dapat dipakai adalah berdasarkan ketetapan yang di jelaskan oleh (Ghozali,2014) yatu pada SEM-PLS jumlah sampel dapat ditentukan antara tigapuluh hingga seratus sampel. 
Penelitian ini mengguankan seratus sampel dikarenakan pertama software Smartpls3.0 yang dimiliki masih student version, kedua adalah kompleksitas dari variabel dan indikator penelitian sehingga dipakai jumlah maksimal sampel pada alat ukur student version, pertimbangan ketiga adalah tidak terdapatnya kerangka sampel yang dapat dijadikan acuan justifikasi. Sehingga sampel penelitian ini ditetapkan sebanyak 100 wisatawan, dengan teknik (cluster) terdiri dari 50 wisatawan nusantara dan 50 wisatawan mancanegara. Penentuan responden menggunakan metode incidental sampling. Data primer penunujang studi ini diperoleh melalui kuisioner, observasi dan wawancara dengan pengelola. Metode analisi data yang digunakan adalah pendekatan kuantitaif berupa model persamaan structural atau SEM-PLS dengan menggunakan Smartpls 3.0 dan juga dijelaskan secara deskriptif sebagai pendukung penelitian ini. Diperoleh hasil karakteristik umum responden dengan rincian: berdasarkan jenis kelamin: responden pria (54) dan responden wanita (46); berdasarkan umur: 16-25 tahun; pekerjaan: Karyawan swasta; kebangsaan Asia; Informasi yang diperoleh : dari teman dan saudara; jumlah kunjungan : didominasi oleh wisatawan yang belum pernah berkunjung sebelumnya.

\section{Hubungan dan model Struktural Penelitian}

Terdapat tujuh hubungan yang memiliki pengaruh langsung maupun pengaruh tidak langsung yang didasari oleh hipotesis penelitian yang diperoleh dari penelitian -penelitian terdahulu lengkap dengan indikator-indikator yang telah diuji pada penelitian sebelumnya. Adapun rincian hubungan sebagai berikut. 


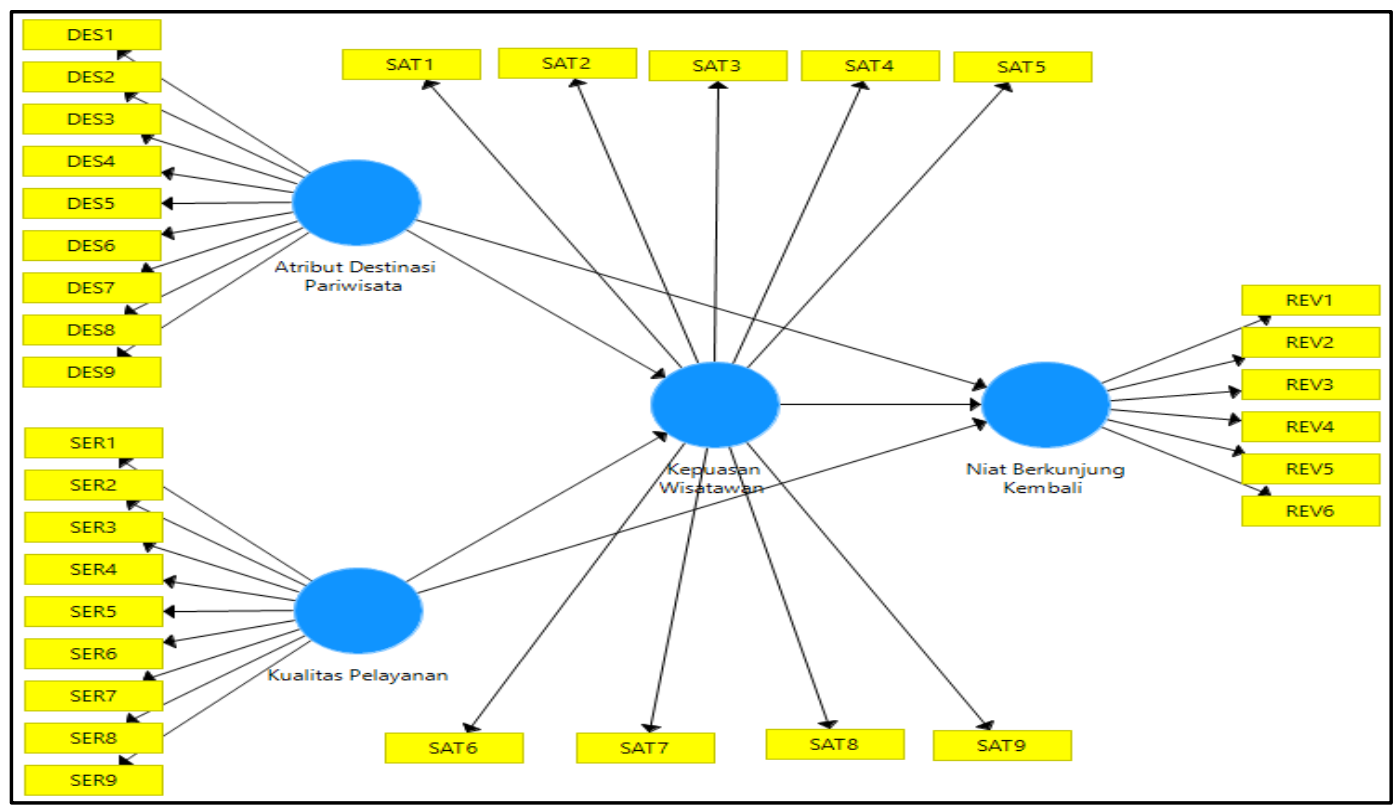

Gambar 1. Hubungan Antar Variable dengan Indikator Sumber: hasil olah data Smart PLS 3.0

Selanjutnya dilakukan uji validitas yaitu dengan melihat nilai outer loading, hubungan antara indikator reflektif dengan variabel pembentuknya. Pada penelitian ini sebagian besar indikator diterima. Terdapat 3 indikator yang harus dieliminasi untuk nantinya model dapat dikatakan layak. Adapun indikator tersebut adalah fasilitas makanan dan minum (restaurant / beach club) dengan nilai loading factor 0,526, ketersediaan lahan parkir dengan nilai loading factor 0,625 , ketersediaan toilet dengan nilai loading factor 0,627. Ketiga indikator tersebut merupakan indikator reflektif dari variabel Atribut Destinasi Pariwisata.

Selanjutnya melakukan uji validitas diskriminan, yaitu dapat diketahui dari nilai cross loading indikator pada variabel pembentuknya. Dimana nilai cross-loading variabel memprediksi indikator reflektif yang dibandingkan dengan variabel pembentuknya sendiri lebih baik dibandingkan dengan indikator dibandingkan dngan variabel ainnya yang bukan variabel pembentuknya. Adapun hasilnya adalah seluruh indikator (total 30 indikator setelah dieliminasi) dengan nilai cross loading 
yang lebih besar jika dihubungkan dengan variabel pembentuknya, jika dibandingkan dengan variabel lain yang bukan variabel pembentuknya. Selanjutnya dilakukan uji reliabilitas dengan composite reliability. Pada penelitian ini, berdasarkan uji reliabilitas, nilai composite reliability serta cronbach alpha > 0.70, maka dapat dikatakan variabel penelitian telah memenuhi reliabilitas variabel yang baik. Setelah itu diuji kelayakan model persamaan structural (inner model).

\section{Uji Kelayakan Model Persamaan Struktural}

Model struktural harus dievaluasi sebelum mengintepretasikan hasil analisis model persamaan struktural, maka daripada itu direkomendsikan untuk melakuka uji kelayakan terhadap model persamaan structural (Fornell \& Larcker, 1981; Chin et al, 2009 dalam Purnami dan Suryawardani, 2018). Model structural dieavaluasi dengan menggunakan R-square. Merujuk pada Ghozali (2014) adapun kriteria hasil $\mathrm{R}^{2}$ yaitu, dikatakan lemah (weakly) apabila range nilainya 0.19-0.32, dikatakan moderat (Moderately) apabila nilainya 0.33-0.66, dikatakan kuat (Substanitially) apabila nilainya $>0.67$. Nilai $R$-square pada penelitian ini dapat dilihat pada tabel dibawah ini.

Tabel 1. Hasil pada $R$-Square

\begin{tabular}{|c|c|c|c|c|c|}
\hline Variabel & $\begin{array}{l}\text { Jenis } \\
\text { Variabel }\end{array}$ & $\begin{array}{l}\text { Jumlah } \\
\text { indikator }\end{array}$ & $\begin{array}{l}\text { Composite } \\
\text { reliability }\end{array}$ & $\begin{array}{l}\text { Average } \\
\text { Variance } \\
\text { Extracted }\end{array}$ & $\mathrm{R} 2$ \\
\hline Atribut Destinasi Pariwisata & Eksogen & 6 & 0.866 & 0.520 & $\mathrm{~N}^{\mathrm{a}}$ \\
\hline kualitas pelayanan & Eksogen & 9 & 0.952 & 0.693 & $\mathrm{~N}^{\mathrm{a}}$ \\
\hline Kepuasan wisatawan & Endogen & 9 & 0.932 & 0.605 & 0.578 \\
\hline $\begin{array}{l}\text { niat wisatawan berkunjung } \\
\text { kembali }\end{array}$ & Endogen & 6 & 0.905 & 0.615 & 0.509 \\
\hline Rata-rata & & - & - & $0.608^{b}$ & 0.544 \\
\hline
\end{tabular}

Sumber: hasil olah data pada Smart Pls 3.0,2019 
Atribut Destinasi Pariwisata dan Kualitas Pelayanan Mempengaruhi Niat Wisatawan...

Pada penelitian ini nilai $R$-Square pada variabel kepuasan wisatawan dengan nilai 0.578, maka model dengan variabel endogen kepuasan wisatawan (SAT) mempunyai kekuatan predikisi dalam kelompok moderat. Artinya sebesar $57.8 \%$ variabel kepuasan wisatawan mampu dijelaskan dengan puas melihat bangunan fisik khas Bali, puas dengan fasilitas makan dan minum, puas dengan penataan fisik DTW, puas melihat aktivitas ritual masyarakat lokal, puas terhadap upaya pengembangan manajemen, puas terhadap harga tiket masuk, puas terhadap kualitas pelayanan, puas terhadap keramahan masyarakat lokal, puas terhadap keseluruhan pengalaman yang dirasakan.

Sedangkan nilai $R^{2}$ variabel niat wisatawan berkunjung kembali dengan nilai 0.509. Artinya model dengan variabel endogen niat berkunjung kembali (REV) memiliki mampu memprediksi dimasukan kedalam kelompok moderat. Dengan nilai sebesar $50.9 \%$ variabel niat berkunjung kembali dapat dijelaskan oleh variabel niat wisatawan berkunjung kembali yaitu, Akan kembali berkunjung karena biaya yang dikeluarkan disini relative murah, Akan kembali karena Pantai Melasti terkenal, Merasa familiar terhadap destinasi pariwisata Pantai Melasti, Akan kembali dengan tujuan khusus atau special, Akan kembali ke destinasi pariwisata Pantai Melasti karena keindahan alamnya, Destinasi pariwisata Pantai Melasti memiliki daya tarik yang unik. Selanjutnya dilihat nilai $f$-square untuk melihat predictor variabel laten, sebagai berikut

Tabel 2. nilai $\mathrm{f}^{2}$ masing-masing variabel laten

\begin{tabular}{|c|c|c|c|c|}
\hline & DES & REV & SAT & SER \\
\hline DES & & 0.100 & 0.086 & \\
\hline \multicolumn{5}{|l|}{ REV } \\
\hline SAT & & 0.123 & & \\
\hline SER & & 0.005 & 0.335 & \\
\hline
\end{tabular}

Sumber: hasil olah data smart PLS 3.0, 2019 
Pertama variabel atribut destinasi pariwisata memiliki pengaruh yang digolongkan kedalam kategori medium dengan nilai 0.100 terhadap variabel niata wisatawan berkunjung kembali, kedua variabel atribut destinasi pariwisata memiliki pengaruh yang lemah dengan nilai 0.086 terhadap variabel kepuasan wisatawan, ketiga variabel kepuasan wisatawan memiliki pengaruh yang dgolongkan ke kategori medium dengan nilai 0.123 terhadap variabel niat wisatawan berkunjung kembali, keempat varibel kualitas pelayanan dengan nilai 0.005 terhadap variabel niat wisatawan berkunjung kembali yang berarti memiliki pengaruh yang lemah, kelima variabel kualitas pelayanan memiliki pengaruh yang kuat sebesar 0.335 terhadap variabel kepuasan wisatawan yang berkunjung di Pantai melasti.

Barulah dilihat goodness of fit model. Lalu dilakukan pengujian pada model persamaan struktural merujuk pada nilai SMRM. Model penelitian dinyatakan telah memenuhi kriteria atau fit dengan syarat nilai SRMR $<0.10$ dan model dinyatakan perfect fit apabila nilai SRMR $<0.08$.

Tabel 3. Pengujian GoF

\begin{tabular}{lll}
\hline & Saturated Model & Estimated Model \\
\hline SRMR & 0.076 & 0.076 \\
\hline d_ULS & 2.652 & 2.652 \\
\hline d_G1 & 1.948 & 1.948 \\
\hline d_G2 & 1.562 & 1.562 \\
\hline Chi-Square & 733.491 & 733.491 \\
\hline NFI & 0.716 & 0.716
\end{tabular}

Sumber: Hasil olah data Smart Pls 3.0, 2019

Berdasarkan tabel 3, menunjukan bahwa nilai SRMR mode sebesar 0.076. maka model ini dinyatakan perfect fit karena nilai model dibawah 0.10 . Sehingga layak digunaan untuk menguji hipotesis penelitian. 


\section{Analisisi Model Pengukuran (Outer Model)}

Adapun hasil dari penelitian setelah memperoleh data dari lapangan adalah sebagai berikut:

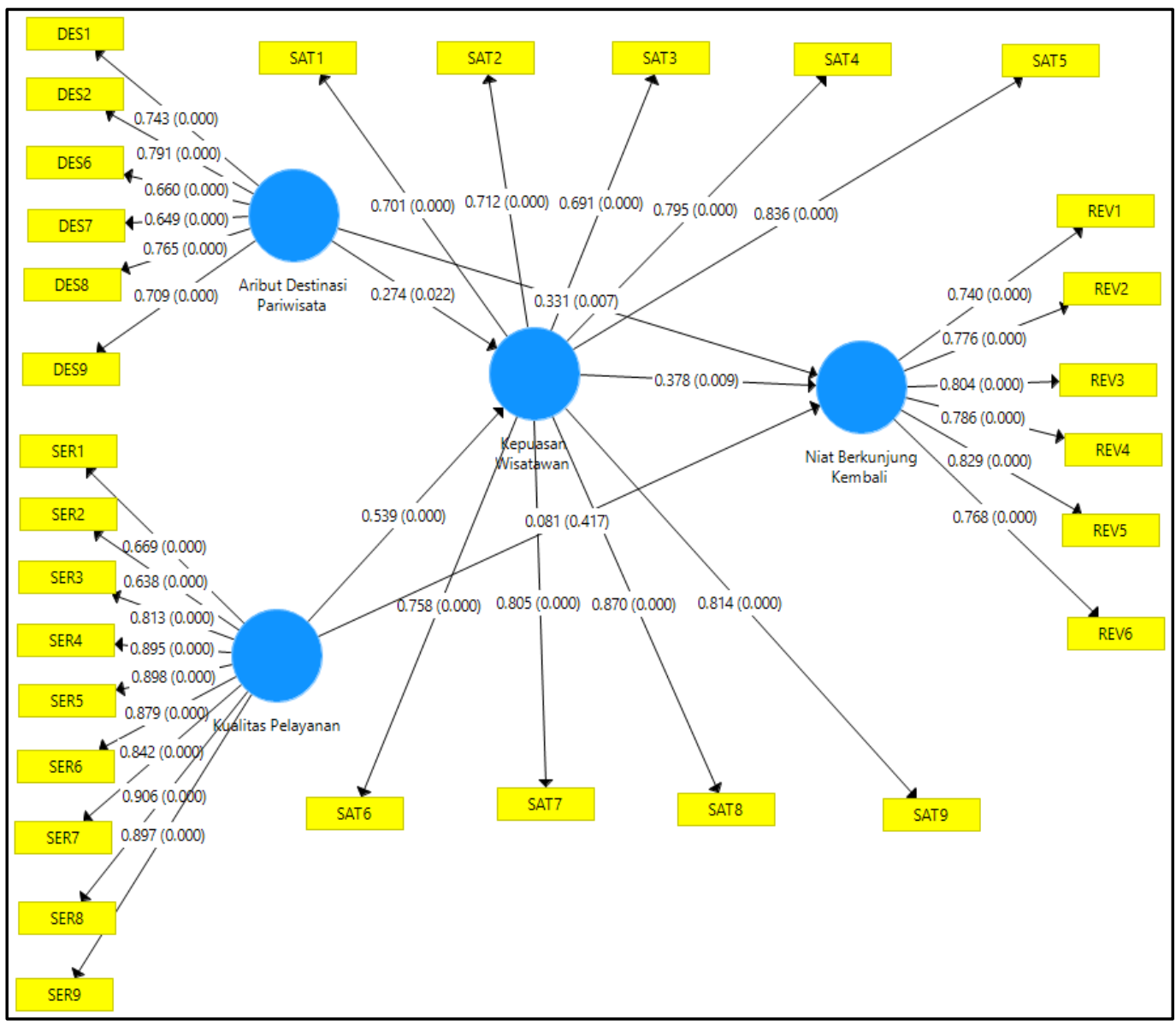

Gambar 2. Output hasil bootstraping model persamaan struktral Sumber: hasil bootsraping smartPLS 3.0

Pada Outer Model, yang perlu diperhatikan adalah nilai loading faktor antara variabel pembentuk dengan indikator reflektifnya oleh Ghozali, (2014) dengan nilai 0.7, walaupun nilai 0.5 dan 0.6 masih bisa dipertimbangkan. Yang perlu dierhatikan adalah masing-masing indikator pada masing-masing variabel. Sehingga dapat menentukan indikator yang memiliki pengaruh paling mendominasi terhadap variabel latennya dan indikator mana yang tidak terlalu signifikan mempengaruhi variabel latennya. 


\section{Hasil analisis model structural (inner model)}

Jika pada outer model yang menjadi titik fokus hubungan antara indikator reflektif dengan variabel pembenuknya. Maka pada inner model yang menjadi titik fokus adalah hubugan antar variabel laten, baik itu hubungan langsung, hubungan tidak langsung, pada bagian terakhir akumulasi dari hubungan langsung dan tidak langsung menjadi total effect.

Tabel 4. Hasil Pengaruh Langsung Antar Variabel

\begin{tabular}{|c|c|c|c|c|c|c|}
\hline Hipotesis & $\begin{array}{l}\text { Var. Eksogenus }>\quad \text { Var. } \\
\text { Endogenus }\end{array}$ & $\begin{array}{l}\text { Original } \\
\text { sample }\end{array}$ & $\begin{array}{l}\text { STD. } \\
\text { Deviasi }\end{array}$ & t & $\begin{array}{l}\mathrm{p}- \\
\text { value }\end{array}$ & \\
\hline H1 & $\begin{array}{l}\text { Aribut destinasi pariwisata }> \\
\text { kepuasan wisatawan }\end{array}$ & 0.274 & 0.127 & 2.157 & 0.031 & ** \\
\hline $\mathrm{H} 2$ & $\begin{array}{l}\text { Kualitas pelayanan> kepuasan } \\
\text { wisatawan }\end{array}$ & 0.539 & 0.087 & 6.166 & 0.000 & ** \\
\hline H3 & $\begin{array}{ll}\text { Atribut destinasi } & \text { pariwisata> } \\
\text { niat wisatawan } & \text { berkunjung } \\
\text { kembali } & \end{array}$ & 0.331 & 0.117 & 2.841 & 0.005 & ** \\
\hline $\mathrm{H} 4$ & $\begin{array}{l}\text { Kualitas pelayanan }>\text { niat } \\
\text { wisatawa berkunjung kembali }\end{array}$ & 0.081 & 0.105 & 0.777 & 0.438 & \\
\hline H5 & $\begin{array}{l}\text { Kepuasan wisatawan }>\text { niat } \\
\text { wisatawan berkunjung kembali }\end{array}$ & 0.378 & 0.144 & 2.631 & 0.009 & ** \\
\hline
\end{tabular}

Sumber: hasil olah data SmartPls 3.0

\section{a. Pengaruh variabel atribut destinasi pariwisata Pantai Melasti Ungasan terhadap variabel kepuasan wisatawan}

Berdasarkan olah data pengujian hipotesis yang pertama dapat disimpulkan bahwa variabel atribut destinasi pariwisata Pantai Melasti Ungasan berpengaruh signifikan terhadap variabel kepuasan wisatawan, dengan nilai original sample sebesar 0.274 (positif) tercatat nilai T statistic dengan nilai 2.195 dan p-value 0.031. Maka diperoleh hubungan yang signifikan dan original sample bertanda positif maka Ho ditolak. Maka atribut destinasi pariwisata Pantai Melasti mempunyai 
pengaruh signifikan terhadap kepuasan wisatawan, hal ini sesuai dengan penelitian yang dilakukan oleh (Sharivar,2012; Corte ,2015; Gnanapala,2015).

Indiktor yang memiliki signifikanis tertinggi yang berperan dalam variabel atribut destinasi pariwisata Pantai Melasti terdapat pada aspek lanskap Pantai Melasti dengan nilai loading sebesar 0.791 dengan nilai $p$-value 0.000 sedangankan yang paling rendah adalah indikator informasi jarak Pantai Melasti ke destinasi terdekat yaitu dengan nilai loading 0.649 serta nilai p-value 0.000. Maka peranan indikator-indikator dalam membentuk variabel memang sudah menunjukkan nilai yang signifikan. Daya tarik wisata Pantai Melasti telah memberikan pengalaman kepada wisatawan yang berkunjung melalui atribut destinasi pariwisata yang dimiliki. Bertitiktolak pada indikator yang harus ditingkatkan yaitu jarak daya tarik wisata Pantai Melasti dengan daya tarik lainnya, disarankan Pengelola Utsaha Pantai Melasti(PUKPM) memberikan penunjuk arah mengenai daya tarik wisata sekitar agar memudahkan wisatawan. Disisi lain ada kecenderungan jarak yang berdekatan dengan daya tarik wisata yang menyajikan pengalaman serupa dan lebih dahulu berkembang seperti daya tarik wisata Pantai Pandawa yang terletak di Desa Kutuh bisa menjadi direct competitor dan bisa menjadi tantangan bagi Pengelola Utsaha Kawasan Pantai Melasti (PUKPM) untuk memperkenalkan Pantai Melasti serta dapat memberikan keyakinan untuk wisatawan berkunjung. Pihak pengelola dapat menggali unique selling point daya tarik wisata Pantai Melasti agar wisatawan yang berkunjung menghabiskan waktunya lebih lama lagi dan tidak beranjak. 

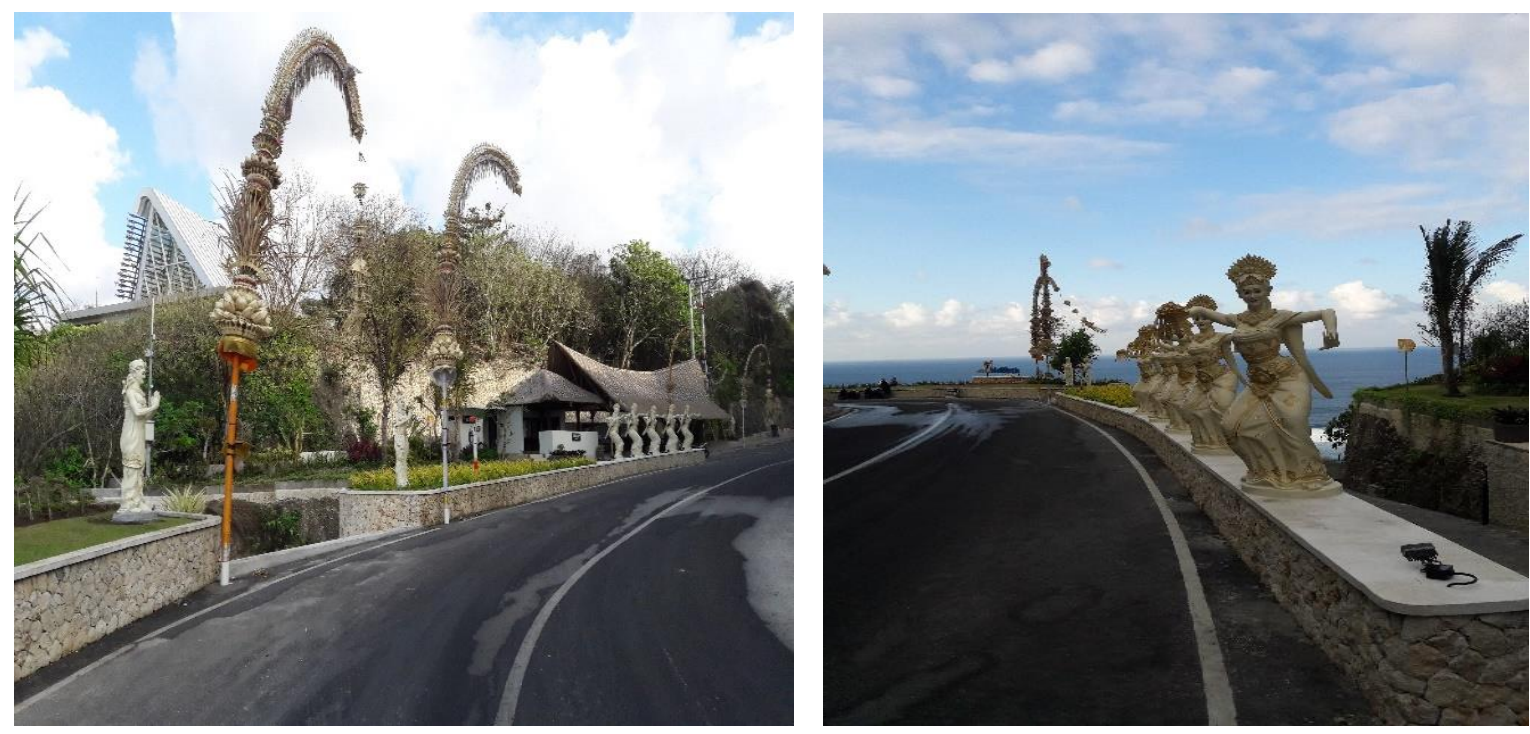

Gambar 3. Jalan akses atau jalan utama menuju Pantai Melasti Sumber : dokumentasi prbadi, penelitian, 2019

\section{b. Pengaruh varaiabel kualitas pelayanan terhadap variabel kepuasan wisatawan}

Pada hipotesis kedua, variabel kualitas pelayanan memiliki pengaruh signifikan terhadap variabel kepuasan wisatawan. Signifikansi yang ditunjukan oleh nilai koefisien jalur sebesar 0.539 (positif), untuk T statistic sebesar 6.166 dan p-value sebesar 0.000. Maka nilai p-value yaitu signifikan dan koefisien jalur bertanda positif maka Ho ditolak, maka kualitas pelayanan berpegaruh positif dan signifikan terhadap variabel kepuasan wisatawan. Hal ini mendukung penelitian yang dilakukan oleh (Tuan, 2012; Al-Ababneh, 2013; Ekinci, dkk, 2008; Hayati dan Desi, 2017; Purnami \& Suryawardani, 2018).

Berdasarkan indikator-indikator pembentuk variabel, seluruh indikator berperan secara signifikan dikarenakan memiliki nilai loading diatas 0.5 atau pada variabel kualitas pelayanan ini nilai loading masing-masing indikator memiliki diatas 0.5. Adapun indikator yang paling signifikan adalah indikator sikap karyawan yang bersahabat terhadap wisatawan dengan nilai outer loading 0.906 dengan nilai p-value $=0.000$. Sedangkan indikator dengan nilia outer loading terlemah adalah SER2 
(kualitas makanan dan minuman yang sesuai ekspektasi tamu) dengan nilai outer loading 0.638 dengan nilai $p$-value $=0.000$. Maka peranan indikator sikap karyawan yang bersahabat dengan tamu menjadi indikator penentu dalam variabel kualitas pelayanan, artinya tamu terkesan dengan pelayanan yang diberikan oleh karyawan baik di ticketing maupun pada pelayanan makanan dan minumnan di daya tarik wisata Pantai Melasti, namun disaat yang bersamaan tamu merasa kualitas makanan dan minuman yang disajikan di daya tarik wisata Pantai Melasti tidak memenuhi ekspektasi meraka, artinya kedepan pihak manajemen pengelola dirasa perlu untuk memfasilitasi pelaku jasa makan dan minum pada Pantai Melasti, untuk diberikan pelatihan baik dari lembaga-lembaga pelatihan.

\section{c. Pengaruh variabel atribut destinasi pariwisata Pantai Melasti Ungasan terhadap variabel niat wisatawan berkunjung kembali}

Berdasarkan pengujian hipotesis ketiga dapat disimpulkan bahwa variabel atribut destinasi pariwisata Pantai Melasti Ungasan memiliki pengaruh signifikan terhadap variabel niat wisatawan berkunjung kembali. Signifikansi ditunjukkan oleh nilai koefisien sebesar 0.331 (positif) dengan niali T statistik sebesar 2.841 dan $p$ value sebesar 0.005. Oleh karena itu, sesuai dengan penelitian yang dipublikasikan oleh (Nusantini, 2016) pengaruh atribut destinasi pariwisata Pantai Melasti memiliki pengaruh signifikan terhadap niat wisatawan berkunjung kembali. Maka semakin baik atribut destinasi pariwisata Pantai Melasti dibenak wisatawan maka niat wisatawan untuk berkunjung kembali akan semakin tinggi, begitupula sebaliknya.

Berdasarkan indikator-indikator pembentuk variabel dan sebagaimana yang sudah dijelaskan pada hipotesis pertama, maka indikator yang paling berpengaruh adalah indikator lanskap yang dimiliki oleh daya tarik wisata Pantai Melasti. Niat wisatawan untuk berkunjung kembali sangat ditentukan oleh keindahan lanskap daya tarik wisata Pantai Melasti sebagai atribut destinasi pariwisata, artinya wisatawan merasakan pengalaman yang baik atau terkesan dengan lanskap daya 
tarik wisata Pantai Melasti. Maka penelitian ini mendukung penelitian yang dilakukan oleh Mat Som et al, (2012). Maka pihak manajemen pengelola sebaiknya memperhatikan lanskap daya tarik wisata Pantai Melasti dalam melakukan penataan kedepan agar lanskap yang dinilia sudah baik oleh wisatawan tetap terjaga dan untuk menghindari keputusan wisatawan untuk tidak lagi mengunjungi daya tarik wisata Pantai Melasti. Pembangunan dan pengembangan yang dilakuakn saat ini sebaiknya tetap mengedepankan aspek lingkungan disaat yang bersamaan juga dapat menjaga estetika daya tarik wisata Pantai Melasti yang eksotis.

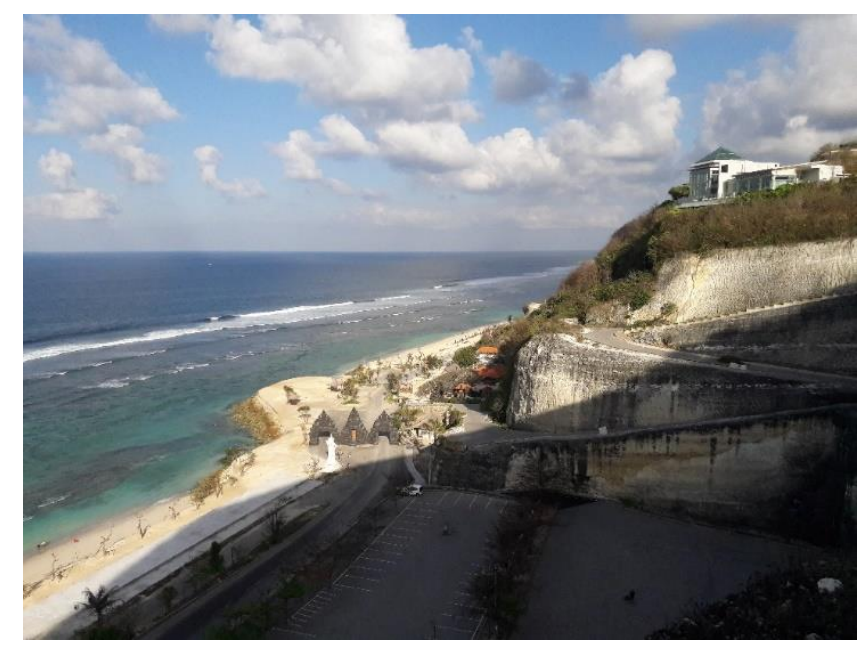

Gambar 4. Lanskap Pantai Melasti dari ketinggian

Sumber : dokumentasi prbadi, penelitian, 2019

\section{d. Pengaruh kualitas pelayanan terhadap niat wisatawan berkunjung kembali}

Berdasarkan hasil pengujian hipotesis keempat dinyatakan bahwa variabel kualitas pelayanan tidak berpengaruh signifikan terhadap variabel niat wisatawan berkunjung kembali, hal ini dinyatakan pada nilai original sample sebesar 0.081(positif), $\mathrm{T}$ statistic sebesar 0.777 dan p-value sebesar 0.438 , nilai $\mathrm{T}$ statistik dibawah dari 1.96 dan nilai p-value yang dihasilkan diatas nilai ambang 0.10 merujuk pada (Ghozali, 2014) maka Ho diterima, disaat bersamaan $\mathrm{H}_{1}$ ditolak. Maka dapat dikatakan tidak sesuai dengan penelitian yang dilakukan oleh (Wong\& Erick,2018), atau hipotesis ini ditolak. Artinya bahwa semakin rendah kualitas 
pelayanan yang diberikan kepada wisatawan maka akan berdampak pada semakin rendahnya keinginan wisatawan untuk berkunjung kembali, begitu pula sebaliknya.

Dengan ditolaknya hipotesis dan jika berbicara tentang kualitas pelayanan akan sangat erat hubungannya dengan kepuasan wisatawan, pernyataan tersebut diperkuat oleh hasil penelitian khususnya pada hipotesis kedua (Tuan,2012; AlAbabneh,2013; Ekinci,dkk,2008; Hayati dan Desi,2017). Pada hubungan kualitas pelayanan lebih kuat jika dihubungkan dengan kepuasan wisatawan sehingga akan menjadi determinant factor wisatawan menjadi loyal dan atau berniat untuk berkunjung kembali (Priyanto dan Hary, (2018).

Berdasarkan pemantauan di lapangan, jika dilihat dari karakteristik tamu yang datang dan melihat atribut destinasi pariwisata lebih sebagai faktor penentu untuk berkunjung jika di bandingkan dengan kualitas pelayanan. Hal ini cukup beralasan, dikarenakan rata-rata wisatawan mancanegara yang datang ke Pantai Melasti sudah menginap di hotel, villa dan guest house dan bahkan sudah mendapatkan pelayanan yang special dari tempat mereka menginap, sehingga apa yang dirasakan wisatawan sangat berbeda jika dibandingkan dengan pelayanan yang diberikan oleh PUKPM begitu urgent.

Di satu sisi Pantai Melasti sesebgaai daya tarik wisata yang mengedepankan keindahan lanskap untuk menarik wisatawan berkunjung, sehingga niat utama wisatawan untuk berkunjung adalah ingin menikmati keindahan lanskap. Sehingga aktivitas pelayanan perlu ditingkatkan.

\section{e. kepuasan wisatawan mempengaruhi niat wisatawan berkunjung kembali}

Pada hasil pengujian hipotesis kelima, dinyatakan bahwa variabel kepuasan wisatawan berpengaruh signifikan terhadap variabel niat wisatawan berkunjung kembali, hal ini dinyatakan pada original sample sebesar 0.378 (beranda positif) dengan nilai T Statistik 2.631 serta $p$-value sebesar 0.009 . Oleh karena nilai $p$-value yang diperoleh signifikan dan original sample bertanda positif maka Ho ditolak, 
maka terdapat kesesuain penelitian yang dilakukan oleh (Bintarti \& Kurniawan, 2017; Al \& Mohammad,2014; Purnami dan Suryawardani, 2018). Dapat disimpulkam bahwa variabel kepuasan wisatawan mempengaruhi secara positif dan signifikan terhadap variabel niat wisatawan berkunjung kembali, artinya semakin tinggi kepuasan yang dirasakan oleh wisatawan maka akan diikuti dengan niat wisatawan yang tinggi untuk berkunjung kembali ke daya tarik wisata Pantai Melasti, begitu pula sebaliknya.

Jika dilihat dari indikator-indikator reflektif, seluruh indikator berperan secara signifikan karena memiliki nilai loading diatas 0.5 . Indikator dalam variabel kepuasan wisatawan yang paling signifikan adalah indikator wisatawan merasa puas terhadap keramahan masyarakat sekitar. Sedangkan indikator loading factor paling lemah adalah indikator yaitu tingkat kepuasan wisatawan melihat penataan fisik daya tarik wisata Pantai Melasti. Mengacu pada hasil penelitian dilapangan, keramahan masyarakat lokal yang terlibat langsung dalam aktifitas kepariwisataan seperti pedagang, petugas ticketing dan pelayan pada beach club memiliki peran penting pada kenyamanan dan kepuasan wisatawan.

Kepuasan wisatawan sangat mempunyai peran penting dalam menciptakan niat wisatawan berkunjung ulang. Hal yang sama dikemukakan oleh Nuraeni, (2014) yang menyatakan kepuasan wisatawan berpengaruh secara signifikan pada niat wisatawan untuk berkunjung kembali. Pada penelitian di Patai Melasti jika ditinjau lebih dalam kepuaan yang dirasakan wisatawan pertama merasa sangat nyaman saat berkunjung terhadap pelayanan yang diberikan, selanjutnya adalah merasa puas dengan pengalaman yang mereka ekspektasikan dapat terpenuhi. Dengan kepuasan inilah yang akan memperkuat niat wisatawan untuk berkunjung kembali. Jika dilihat dari aspek kepuasan wisatawan, kualitas pelayanan yang paling berpengaruh positf dan signifikan terhadap kepuasan wisatawan jika dibandingkan dengan atribut destinasi wisata. 
Selanjutnya, adapun hasil pengaruh melalui perantar atau tidak langsung dengan kepuasan wisatwan dengan rincian sebgaia berikut

Tabel 5. Hasil Pengaruh Tidak Langsung

\begin{tabular}{lllllll}
\hline & Var. Eksogenus & $>$ Var. & Original & & $\mathrm{t}$ & \\
Hipotesis & Endogenus & & sample & STD.Deviasi & statistic & p-value \\
\hline H6 & DES>SAT>REV & 0.103 & 0.069 & 1.505 & 0.133 \\
H7 & SER>SAT>REV & 0.204 & 0.083 & 2.462 & 0.014 & $* *$
\end{tabular}

Sumber: hasil olah data Smart Pls 3.0

Adapun detail intepretasinya sebagai berikut,

\section{a. Pengaruh atribut destinasi pariwisata Pantai Melasti terhadap niat wisatawan berkunjung kembali dengan kepuasan wisatawan sebagai intervening}

Berdasarkan hasil pengujian hipotesis ke enam, hubungan antara variabel atribut destinasi pariwsata tidak berpengaruh signifikan terhadap niat wisatwan berkunjung kembali jika melalui variabel kepuasan wisatawan, hal ini menolak penelitian yang dilakukan oleh Chan (2018), mengindikasikan bahwa variabel kepuasan wisatawan bukan sebagai variabel penghubung yang baik antara variabel atribut destinasi pariwisata Pantai Melasti dengan variabel niat wisatawan berkunjung kembali. Jika dilihat pada indikator-indikator pembentuk variabel atribut destinasi pariwsata dan variabel kepuasan wisatawan, pada variabel atribut destinasi pariwisata Pantai Melasti indikator yang memiliki signifikansi tertinggi adalah lanskap, sedangankan nilai yang paling rendah adalah indikator jarak Pantai Melasti ke destinasi terdekat.

Berdasarkan hasil penelitian dilapangan, diketahui bahwa variabel kepuasan wisatawan bukan variabel penghubung yang baik antara pengaruh atribut destinasi pariwisata Pantai Melasti terhadapat niat wisatawan berkunjung kembali. Artinya 
variabel atribut destinasi pariwisata Pantai Melasti tidak memerlukan variabel penghubung. Seperti halnya pada hipotesisi ketiga, yaitu pengaruh variabel atribut destinasi pariwisata mempengaruhi secara signifikan terhadap niat wisatawan berkunjung kembali tanpa melalui variabel penghubung.

\section{b. kualitas pelayanan mempengaruhi niat wisatawan berkunjung kembali melalui kepuasan wisatawan}

Pada hipotesis ke tujuh, dinyatakan pengaruh kualitas pelayanan berpengaruh signifikan terhadap niat wisatawan berkunjung kembali melalui kepuasan wisatawan sebagai variabel intervening. Dengan nilai koefisien jalur sebesar 0.204 (positif), T Statistik sebesar 2.462 dan nilai p-value sebesar 0.014. Maka dapat dikatakan hasil penelitian ini sejalan penelitian yang dilakukan oleh (Priyanto et, al,2018; Nunkoo,2018; Purnami dan Suryawardani, 2018).

Jika dilihat pada indikator-indikator pada variabel kualitas pelayanan maupun pada variabel kepuasan wisatawan adalah sebagai berikut. Pada variabel kualitas pelayanan adapun indikator dengannilai loading terbesar adalah staff yang bertugas pada ticketing dan beach club melayanai tamu dengan hangat. Sedangkn indikator dengan nilai loading factor terendah adalah kualitas makanan dan minuman yang tidak sesuai dengan ekspektasi wisatawan. Selanjutnya adapun indikator yang memiliki nilai loading factor terbesar pada variabel kepuasan wisatawan adalah indikator puas terhadap keramahan masyarakat lokal. Sedangkan indikator dengan nilai loading paling lemah adalah kepuasan wisatawan melihat penataan fisik Pantai Melasti. Dapat dinyatakan bahwa semakin tinggi kualitas pelayanan yang diberikan kepada wisatawan maka wisatawan akan semakin puas dan tentu akan menimbulkan semakin tingginya niat wisatawan untuk berkunjung kembali di daya tarik wisata Pantai Melasti. Maka berdasarkan hasil penelitian ini objek dari kualitas pelayanan adalah karyawan yang melayani wisatawan, maka kompetensi dan kecakapan karyawan dalam memberikan 
pelayanan harus ditingkatkan dengan cara pelatihan, workshop, maupun sertifikasi dari lembaga-lembaga sertifikasi guna menciptakan pelayanan yang sesuai dengan standard dan seragam satu sama lainnya.

Dapat dikatakan bahwa variabel kualitas pelayanan bukanlah variabel penentu untuk menciptakan niat wisatawan untuk berkunjung kembali. Kendati pengaruh kualitas pelayanan terhadap niat wisatawan berkunjung kembali dengan kepuasan wisatawan memiliki pengaruh secara positf dan signifikan. Namun hasil ini semakin menunjukkan bahwa variabel kualitas pelayanan tidak cukup kuat untuk mempengaruhi niat wisatawan berkunjung kembali terbukti pada hipotesisi sebelumnya yaitu hipotesis ke empat dimana variabel kualitas pelayanan tidak berpengaruh jika dihubungkan langsung dengan variabel niat wisatwan berkunjung kembali.

Maka diperlukan variable penghubung yang kuat. Dalam konteks penelitian ini adalah variabel kepuasan wisatawan. Maka hasil studi ini sekaligus membantah penelitian yang dilakukan oleh Akinci,(2003) yang dalam penelitiannya menyatakan kualitas pelayanan merupakan salah satu dari beberapa faktor yang penting untuk menentukan sebuah destinasi dikatakan sukses. Maka dapat dikatakan variabel atribut destinasi pariwisata yang merupakan variabel yang paling kuat pengaruhnya untuk menciptakan niat wisatawan berkunjung kembali. Variabel kualitas pelayanan sebagai pendukung untuk memberikan kepuasan wisatawan yang sedang berkunjung selama di daya tarik wisata Pantai Melasti.

Selanjutnya adalah Total effect, merupakan akumalasi dari pengaruh secara langsung dengan pengaruh secara tidak langsung membentuk pengaruh total. 
Tabel 6. Pengaruh total antar variabel laten

\begin{tabular}{|c|c|c|c|c|c|c|c|}
\hline Variabel eksogenus & & $\begin{array}{l}\text { Variabel } \\
\text { endogenus }\end{array}$ & $\begin{array}{l}\text { Outer } \\
\text { Loading }\end{array}$ & STD.Deviasi & $\begin{array}{l}\mathrm{t} \\
\text { statistic }\end{array}$ & $\begin{array}{l}\mathrm{p}- \\
\text { value }\end{array}$ & \\
\hline $\begin{array}{ll}\text { Atribut } & \text { Destinasi } \\
\text { Pariwisata } & \end{array}$ & $>$ & $\begin{array}{l}\text { Kepuasan } \\
\text { wisatwan }\end{array}$ & 0.274 & 0.127 & 2.157 & 0.031 & ** \\
\hline Kualitas pelayanan & $>$ & $\begin{array}{l}\text { Kepuasan } \\
\text { wisatwan }\end{array}$ & 0.539 & 0.087 & 6.166 & 0.000 & ** \\
\hline $\begin{array}{ll}\text { Atribut } & \text { Destinasi } \\
\text { Pariwisata } & \end{array}$ & $>$ & $\begin{array}{l}\text { Niat } \\
\text { berkunjung } \\
\text { kembali }\end{array}$ & 0.435 & 0.112 & 3.892 & 0.000 & ** \\
\hline Kualitas pelayanan & $>$ & $\begin{array}{l}\text { Niat } \\
\text { berkunjung } \\
\text { kembali }\end{array}$ & 0.285 & 0.100 & 2.859 & 0.004 & ** \\
\hline Kepuasan wisatawan & $>$ & $\begin{array}{l}\text { Niat } \\
\text { berkunjung } \\
\text { kembali }\end{array}$ & 0.378 & 0.144 & 2.631 & 0.009 & ** \\
\hline
\end{tabular}

Sumber: data hasil penelitian dilapangan, menggnakan smart PLS 3.0, 2019

Adapun yang terakumalsi dari total effect ini adalah, pertama Nilai koefisien yang disajikan pada hubungan variabel Atribut destinasi pariwisata dengan variabel niat wisatawan berkunjung kembali didapat dari gabungan antara direct effect dan indirect effect sehingga didapatkan nilai 0.435 (positif) signifikan pada 5\% ( T value > 1.96) T statistik sebesar 3.892 dan $p$-value sebesar 0.000 artinya hubungan total effect yang terbentuk dari gabungan direct dan indirect effect pada variabel atribut destinasi pariwisata Pantai Melasti terhadap niat wisatawan berkunjung kembali mempunyai pengaruh positif dan sangat signifikan.

Kedua, hubungan kualitas pelayanan terhadap variabel niat wisatawan berkunjung kembali didapat dari gabungan antara direct effect dan indirect effect sehingga didapatkan nilai original sample sebesar 0.285 signifikan pada $5 \%$ ( $\mathrm{T}$ value > 1.96), berdasarkan hasil olah data didapatkan T statistic dengan nilai 2.859 dan $p$ value sebesar 0.004 artinya hubungan total yang terbentuk dari gabungan direct dan 
Atribut Destinasi Pariwisata dan Kualitas Pelayanan Mempengaruhi Niat Wisatawan...

indirect effect pada hubungan kualitas pelayanan terhadap niat wisatawan berkunjung kembali memiliki pengaruh positif dan sangat signifikan .

\section{Simpulan dan Saran}

Penelitian ini telah mampu menjawab pokok permasalahan yang menjadi pertanyaan penelitian. Pengujian model struktur hubungan baik pengaruh secara langsung maupun secara tidak langsung telah mampu menjawab tujuh sub-pokok permasalahan yang dapat disimpulkan sebagai berikut. Pertama, Atribut Destinasi Pariwisata Pantai Melasti berpengaruh signifikan terhadap kepuasan wisatawan. Kedua, kualitas pelayanan berpengaruh signifikan terhadap kepuasan wisatawan. Ketiga, Atribut Destinasi Pariwisata Pantai Melasti berpengaruh signifikan terhadap niat wisatawan berkunjung kembali. Keempat, namun pada penelitian kualitas pelayanan tidak berpengaruh signifikan terhadap niat wisatawan berkunjung kembali, maka hipotesis ditolak. Maka kualitas pelayanan tidak sepenuhnya mempengaruhi niat wisatawan untuk berkunjng kembali pada Daya Tarik Wisata Pantai Melasti. Kelima, kepuasan wisatawan berpengaruh signifikan terhadap niat wisatawan berkunjung kembali. Artinya semakin tinggi tingkat kepuasan wisatawan maka semakin tinggi pula niat wisatawan untuk berkunjung kembali, begitu juga sebaliknya. Keenam, Atribut Destinasi Pariwsata tidak berpengaruh signifikan terhadap niat wisatwan berkunjung kembali melalui variabel kepuasan wisatawan, maka hipotesis ditolak. Dapat dikatakan bahwa variabel Atribut Destinasi Pariwisata bukan merupakan variabel intervening yang baik dalam hubungan antara variabel Atribut Destinasi Pariwisata Pantai Melasti terhadap niat wisatawan berkunjung kembali.Ketujuh, variabel kualitas pelayanan berpengaruh signifikan terhadap niat wisatawan berkunjung kembali melalui variabel kepuasan wisatawan. Dapat dikatakan bahwa variabel kepuasan wisatawan merupakan variabel intervening yang baik dalam hubungan antara variabel kualitas pelayanan terhadap niat wisatawan berkunjung kembali. 
Adapun saran yang dapat ditawarkan bertitik tolak pada kesimpulan adalah, Mempertahankan indikator Atribut Destinasi Pariwisata Pantai Melasti yaitu pertama, lanskap agar tetap terjaga keindahan secara estetika sehingga membuat wisatwan merasa puas untuk berkunjung.kedua, mempertahankan kualitas pelayanan yang diberikan kepada tamu terutama pada sikap Karyawan yang bersahabat dengan tamu yang berkunjung sehingga menciptakan kepuasan wisatawan pada saat berkunjung. Ketiga, mempertahankan indikator Atribut Destinasi Pariwisata Pantai Melasti yaitu keindahan lanskap dan sejalan dengan penataan yang mendepankan aspek lingkungan sehingga menciptakan niat wisatawan untuk berkunjung kembali. Hal ini dapat menjadi sarana terutama pada platform media sosial, karena wisatawan yang berkunjung ke Pantai Melasti cenderung mengabadikan moment dengan berfoto menikmati atribut destinasi pariwisata yang dimiliki Pantai Melasti dan mengunggahnya pada akun media sosial mereka. Agar membuat tempat swa foto yang instagramable sehingga dapat menarik niat wisatawna untuk melakukan foto, Keempat, meningkatkan kualitas pelayanan guna meningkatkan niat wisatawan berkunjung kembali, dengan cara melakukan pelatihan dari instansi resmi dan universitas atau sekolah tinggi yang membidangi pelayanan industri pariwisata dan juga melakukan akreditasi guna menciptakan pelayanan yang sesuai standard an seragam. Kelima, mempertahankan tingkat kepuasan wisatawan guna menciptakan niat wisatawan untuk berkunjung kembali dimasa mendatang. Indikator keramahan masyarakat sekitar menjadi indikator yang paling kuat sebagai faktor pembentuk variabel kepuasan wisatawan. Maka sangat perlu meningkatkan dan menanamkan pemahaman sadar wisata bagi masyarakat Desa Adat Ungasan sebagai tuan rumah dari kegiatan pariwisata tersebut. Keenam, meningkatkan kepuasan wisatawan dalam hubungan pengaruh tidak langsung Atribut Destinasi Pariwisata Pantai melasti Ungasan dengan niat wisatawan berkunjung kembali. Saat hubungan Atribut Destinasi Pariwsata Pantai Melasti Ungasan terhadap niat wisatawan berkunjung kembali melalui kepuasan 
wisatawan menunjukan tidak ada pengaruh. Maka kepuasan wisatawan menjadi salah satu hal yang penting dan perlu diperhatikan untuk terus ditingkatan guna menciptakan niat wisatawan berkunjung kembali. Ketujuh, mempertahankan tingkat kepuasan wisatawan dalam hubungan pengaruh secara tidak langsung kualitas pelayanan terhadap niat wisatawan berkunjung kembali. Pentingnya kepuasan wisatawan saat berkunjung memberikan dampak positif dan signifikan terhadap kualitas pelayanan terhadap niat wisatawan berkunjung kembali.

Saran untuk penelitian selanjutnya adalah, pertama penelitian yang lebih mencondongkan kepada perilaku wisatawan agar penelitian ini berkesinambungan, kedua adalah memperhatikan indikator-indikator penelitian yang dinamis, dikarenaka needs, want, dan demand wisatawan sangat dinamis dan cepat berubah.

\section{Daftar Pustaka}

Al, Bashar Aref Mohammad \&Haj Mohammad.2014. ExaminingTourist satisfaction, Loyalty and ntention to Revisit. International journal of Managments Science Vol. 2, No. 6, pp: 260-273

Al-Ababneh, M. (2013). Service Quality and its Impact on Tourist Satisfaction. Interdisciplinary Journal of Contemporary Research In Business, 4(12), 164-177

Bintari,Surya \& Ergo Nupatria Kurniawan.2017.A Study of Revisit intention: Experiential Quality and Image of Muara Beting Tourism Site in Bkasi District. European Research studies journal. Volume XX, Issue 2A

Ekinci, Y., Dawes, P.L., \& Massey, G.R. (2008). An Extended Model of the Antecedents and Consequences of Consumer Satisfaction for Hospitality Services. European Journal of Marketing, 42(1/2), 35-68

Corte, Valentina Della, et al,.2015.Customer satisfaction in tpurist destination: the case of tourism offer in the city of Naples. Journal of investment management 2015;4 (1-1)

Cohen, Scott, Miguel Moital \& Girish Prayag. 2014. Consumen behavior in tourism: Concepts, influences, and opportunities. Current Issues in Tourism, 2014 Vol. 17, No. 10, 872-909, 
Chan,Syafruddin. 2018. Factors affecting revisit intention with customer satisfaction as a mediating variable in eco friendly resort. JMI Vol 9 (1) (2018): 1 - 13

Diarta, I Ketut Surya. 2018. Usulan Pemberian Status Daya Tarik Wisata (DTW) Pantai Melasti Desa adat Ungasan Dari Pemerintah Kabupaten Badung (CQ. Bupati Badung). Draft Naskah Kajian akademik : Ungasan

Gnanapala, W.K. Athula. 2015.Tourist perception and satisfaction: implication for destination management. American journal of marketing research, Vol 1, No. 1 pp: 7-19

Ghozali, Imam.2014.Structural Equation Modeling metode alternative dengan partial least squares (PLS).Semarang : Universitas Diponogoro

Hayati, Nur \&Desi Novitasari.2017.An Analysis of Tourism service Quality Toward Customer Satisfaction (Study on Tourist In Indonesia Travel Destination To Bali). International Journal of Marketing and Human Resource Management (IJMHRM) Volume 8, pp. 09-20

Jani, et.al,.2009. Differential Effect Of Tourism Resources on the Attractiveness of Destination Bundless. International Journal of tourism science 9 (1): 23-36

Kozak, Metin and Mike Rimmington. 1999. Measuring Tourist Destination Competitiveness: Conceptual Considerations And Empirical Findings. Hospitality Management, Vol. 18 No.1, pp. 273-283

Machleit K.A \& S. P. Mantel. 2001."Emotional response and shopping satisfaction: moderating effects of shopper attributions,". Journal of Business Research, v. 54, pp. 97-106

Nusantini, Ni Luh Ayu. Atribut Destinasi mempengaruhi loyalitas wisatawan berkujung ke kawasan Sanur. JUMPA Volume 2 Nomor 2 Januari 2016

Nunkoo, Robin.2018. Destination satisfaction and revisit intention of tourists: Does the quality of airort service matter?. Journal of Hospitality \& Tourism Research

Parasuraman, A., Zeithaml, V. A., \& Berry, L. (1985). A conceptual model of service quality and its implications for future research. Journal of Marketing(41-55)

Priyanto, Rahmat, dkk. 2018. Pengaruh kualitas pelayanan terhadap kepuasan wisatawan serta dampaknya terhadap loyalitas (studi di ciater spa resort). STP AMPTA : Yogyakarta

Purnami, Ni Nyoman Alit \& I Gusti Ayu Oka Suryawardani. 2018. The effect of the quality of services on the visitors satisfaction and desire to pay a revisit to the Bali Pulina Agrotourism. E-Journal of Tourism Vol. 5. No.2 : 62-71

Robertson, R.A \& J. A Regula. 1994.Recreational displacement and Overall Satisfaction: a study of central Lowa's Licensed Boater. Journal Leisure Res, 26 : 174-181 
Solomon,M.R.1992.Consumer Behavior. Singapore : Prentice

Shahrivar, Rafat Beigpoor. 2012.Factors that influence tourist satisfaction.Journal of travel and tourism research, special issue destination management-2012

Tuan, N.M. (2012). Effects of Service Quality and Price Fairness on Student Satisfaction. International Journal of Business and Social Science, 3(19), 132-150

Wang. Y dan H. P. Lo, Y. Yang. 2004 “An integrated framework for service quality, customer value, satisfaction: evidence from China's telecommunication industry.Journal Information Systems Frontiers, v. 6, pp. 325-340

Wong, Nurdiana \& Eric Lui. 2018. Satisfaction Drivers and Revisit Intention of International Tourists in Malaysia.Journal of Tourism, hospitality and environment management. Volume: 3 Issues: 9 [June, 2018] pp.01-13.

Zeithamal, V.A, M.J Bitner \& D.D Gremler. 2009. Services Marketing : Integrating Customer Focus Accros the Firm . Mc Grawhill : New York

\section{Profil Penulis}

Made Riki Ponga Kusyanda adalah Alumnus Sarjana Sains Terapan Pada Sekolah Tinggi Pariwisata Nusa Dua Bali pada tahun 2016 dan melanjutkan Pendidikan Program Magister di Program Studi S2 Pariwisata, Universitas Udayana

Prof. Dr. Ir. Made Antara, MS, selaku pembimbing satu, merupakan Guru Besar Fakultas Pertanian Universitas Udayana. Serta aktif mengajar pada S2 Pariwisata serta aktif mengajar pada S3 Pariwisata, Universitas Udayana. Adapun bidang keahlian beliau adalah pemodelan system penelitian Pariwisata maupun Pertanian.

Dr. Ir. I Gusti Ayu Oka Suryawardani, M.Mgt., PhD, selaku pembimbing dua. Adapun bidang keahlian beliau adalah ekonomi pariwisata, permodelan system penelitian pariwisata maupun pertanian, dan perilaku konsumen. 